\title{
Annals of Communism
}

Each volume in the series Annals of Communism will publish selected and previously inaccessible documents from former Soviet state and party archives in a narrative that develops a particular topic in the history of Soviet and international communism. Separate English and Russian editions will be prepared. Russian and Western scholars work together to prepare the documents for each volume. Documents are chosen not for their support of any single interpretation but for their particular historical importance or their general value in deepening understanding and facilitating discussion. The volumes are designed to be useful to students, scholars, and interested general readers. 


\section{FOUNDING EDITOR OF THE ANNALS OF COMMUNISM SERIES}

Jonathan Brent, Yale University Press

\section{AMERICAN ADVISORY COMMITTEE}

Ivo Banac, Yale University

Zbigniew Brzezinski (deceased), Center for

Strategic and International Studies

William Chase, University of Pittsburgh

Friedrich I. Firsov, former head of the

Comintern research group at RGASPI

Sheila Fitzpatrick, University of Chicago

Gregory Freeze, Brandeis University

John L. Gaddis, Yale University

J. Arch Getty, University of California, Los Angeles

Jonathan Haslam, Cambridge University
Robert L. Jackson, Yale University

Norman Naimark, Stanford University

Gen. William Odom (deceased), Hudson Institute and Yale University

Daniel Orlovsky, Southern Methodist University

Timothy Snyder, Yale University

Mark Steinberg, University of Illinois, Urbana-Champaign

Strobe Talbott, Brookings Institution

Mark Von Hagen, Arizona State University

Piotr Wandycz, Yale University

\section{RUSSIAN ADVISORY COMMITTEE}

K. M. Anderson, Moscow State University

N. N. Bolkhovitinov, Russian Academy of Sciences

A. O. Chubaryan, Russian Academy of Sciences

V. P. Danilov, Russian Academy of Sciences

A. A. Fursenko, secretary, Department of History, Russian Academy of Sciences (head of the Russian Editorial Committee)

V. P. Kozlov
N. S. Lebedeva, Russian Academy of Sciences

S. V. Mironenko, director, State Archive of the Russian Federation (GARF)

O. V. Naumov, director, Russian State Archive of Social and Political History (RGASPI)

E. O. Pivovar, Moscow State University

V. V. Shelokhaev, president, Association ROSSPEN

Ye. A. Tyurina, director, Russian State Archive of the Economy (RGAE) 


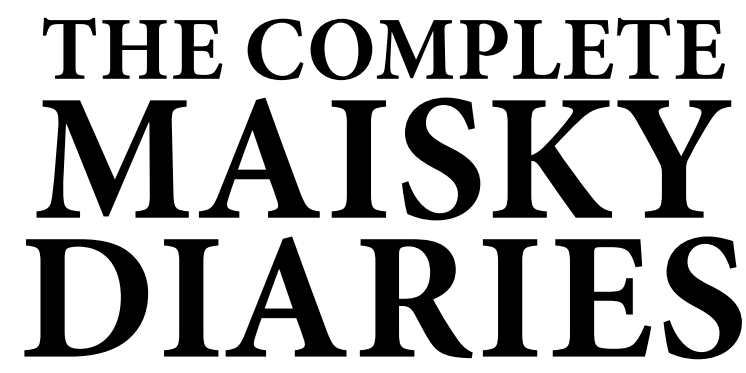

VOLUME 1

THE RISE OF HITLER AND

THE GATHERING CLOUDS OF WAR 1932-1938

\section{EDITED BY GABRIEL GORODETSKY}

Translated by Tatiana Sorokina and Oliver Ready 
Copyright $\odot 2017$ by Gabriel Gorodetsky.

All rights reserved.

This book may not be reproduced, in whole or in part, including illustrations, in any form (beyond that copying permitted by Sections 107 and 108 of the U.S. Copyright Law and except by reviewers for the public press), without written permission from the publishers.

Published with the permission of the Scheffer-Voskressenski family-Ivan Maisky's heirs. Photographs from Agniya Maisky's album are published with the permission of the Voskressenski family, owners of the copyright and Ivan Maisky's heirs.

Yale University Press books may be purchased in quantity for educational, business, or promotional use. For information, please e-mail sales.press@yale.edu (U.S. office) or sales@ yaleup.co.uk (U.K. office).

Set in Minion Pro and ITC Stone Sans type by Newgen. Printed in the United States of America.

Library of Congress Control Number: 2017942542

ISBN 978-0-300-11782-0 (hardcover : alk. paper)

A catalogue record for this book is available from the British Library.

This paper meets the requirements of ANSI/NISO Z39.48-1992 (Permanence of Paper).

10987654321 
Yale University Press gratefully acknowledges the financial support given for this publication by the John M. Olin Foundation, the Lynde and Harry Bradley Foundation, the Historical Research Foundation, Roger Milliken, the Rosentiel Foundation, Lloyd H. Smith, Keith Young, the William H. Donner Foundation, Joseph W. Donner, Jeremiah Milbank, the David Woods Kemper Memorial Foundation, and the Smith Richardson Foundation. 
This page intentionally left blank 